\title{
Fiscal Federalism and Regional Growth Evidence from the Russian Federation in the 1990s ${ }^{*}$
}

\author{
Raj M. Desai \\ Georgetown University
}

Lev M. Freinkman

The World Bank
Itzhak Goldberg

The World Bank

World Bank Policy Research Working Paper 3138, September 2003

The Policy Research Working Paper Series disseminates the findings of work in progress to encourage the exchange of ideas about development issues. An objective of the series is to get the findings out quickly, even if the presentations are less than fully polished. The papers carry the names of the authors and should be cited accordingly. The findings, interpretations, and conclusions expressed in this paper are entirely those of the authors. They do not necessarily represent the view of the World Bank, its Executive Directors, or the countries they represent. Policy Research Working Papers are available online at http://econ.worldbank.org.

\footnotetext{
* The authors are grateful to Galina Kurlayndskaya and Natalia Golovanova from the Center for Fiscal Policy for providing regional fiscal data used in this paper, and to Boris Kopeikin from the Institute of Urban Economy for arranging travel to Yaroslavl. Jorge Ugaz provided invaluable research assistance, and financial support was provided by the World Bank's research preparation grants program, RPG No. RF-P074267-RESE. The authors thank Jackie Coolidge, John Litwack, Helga Muller, Stepan Titov, Dana Weist, Deborah Wetzel and other participants of the World Bank seminar for their comments and suggestions on earlier drafts of the paper.
} 


\begin{abstract}
Sub-national fiscal autonomy - the basis for fiscal federalism in modern federations - is meant to serve two roles. First, local control over revenue collection is meant to provide a check on the capacity of central authorities to tax arbitrarily local capital. Second, retention of taxes raised locally is meant to establish incentives for sub-national governmental authorities to foster endemic economic growth as a way of promoting local tax bases. In the Russian Federation, however, fiscally autonomous regions have often resisted market-oriented reforms, the enactment of rule protecting private property, and the dismantling of price controls and barriers to trade. This paper finds statistical evidence in support of the hypothesis that fiscal incentives of the Russian regions represent an important determinant of regional economic performance. Moreover, it seeks to understand the conditions under which fiscal autonomy prompts regional growth and recovery, and the conditions under which it has adverse economic effects. The paper argues that the presence of "unearned" income streams - particularly in the form of revenues from natural resource production or from budgetary transfers from the central government-has turned regions dependent on these income sources into "rentier" regions. As such, governments in these regions have used local control over revenues and expenditures to shelter certain firms (natural resource producers or loss-making enterprises) from market forces. Using new fiscal data from 80 Russian regions during the period 1996-1999, we test this central hypothesis in both single- and simultaneous-equation specifications. Our results indicate that tax retention (as a proxy for fiscal autonomy) has a positive effect on the cumulative output recovery of regions since the break-up of the Soviet Union. We also find, however, that this effect decreases as rentable income streams to regions increase.
\end{abstract}




\section{Introduction}

Revenue is central to state formation. Revenue collection also binds the state to the public in different ways (Tilly and Ardant 1975). The ability of rulers to tax capriciously local capital potentially creates a severe credibility problem, significantly limiting new investment and economic growth. By contrast, "ruleful" (stable, predictable) tax policies have often historically presaged the rise of meritocracy and the spread of the rule of law in state administrations (North and Weingast 1990). For theorists such as Madison and Montesquieu, the separation of powers - not merely between branches of government, but between levels of governmentprovided a constitutional check on the capacity of central authorities to expropriate local wealth. As Madison understood, however, governments at all levels are capable of expropriation; a fiscal division of powers between central and sub-national government would be necessary to constrain the powers of each. Thus, a potential consequence of fiscal federalism is to afford sub-national governments incentives to promote local economic growth.

In the Russian Federation, however, struggles between central and sub-national authorities remain a significant obstacle to economic reform and recovery. As the regional governments began to exert greater authority over local resources, enterprises, and fiscal policy, the federal government's ability to police the common market came under considerable strain. Although several regions have embraced markets, protected private property, and removed barriers to trade, others have actively resisted these reforms - despite efforts in recent years to reassert federal authority in these areas. The diverse Russian regional experience, therefore, affords an opportunity to understand the conditions under which federalism is, alternatively, "market-preserving" or "market-subverting."

In this regard, the diverging economic performance of China and Russia is instructive. Evidence from China's provinces suggests that, in contrast to the Russian experience, provincial authorities have strongly supported market reforms and have promoted local entrepreneurship. There are two views regarding the differences between China and Russia. In one view, China's remarkable rate of economic growth over the past twenty years is due to Chinese-style fiscal federalism that gives strong fiscal incentives to the sub-national governments to develop a sustainable source of local tax revenues by supporting new private businesses and enterprise restructuring. As a result, local firms in China avoid excessive administrative interference as local governments shield these firms from corruption and over-regulation in order to protect their local tax base (Montinola, Qian, and Weingast 1994; Jin, Qian, and Weingast 2000). In contrast, Russian intergovernmental financial policies have generally failed to provide local governments with any significant degree of control over revenues. Thus, their incentives to improve tax collections or expand the local tax base are weak. Limited local control over local finances, therefore, has resulted in major barriers for the growth of new firms, which have fallen prey to predatory taxation, regulation, or corruption.

A second view is that Chinese economic reforms have occurred against the backdrop of political centralization, whereas reform in Russia proceeded alongside the chaos of political decentralization and democratization (Blanchard and Shleifer 2001). In China, unlike the Russian Federation, the Party-State remains intact and its ability to reward and punish subnational actors undiminished. More importantly, the capacity of the central government to collect accurate information from provincial governments remains high (Huang 1994). 
Intergovernmental relationships in Russia, by contrast, are characterized by highly unstable and overlapping divisions of authority, as both regional and central politicians have struggled to fill the void brought about by the collapse of the Soviet State.

These contrasting views imply different perceptions of the effect of fiscal federalism on economic performance. The first view suggests that tax retention and expenditure management by local governments will prompt local governments to protect their local tax base from expropriation by managers or corrupt government officials. The second view suggests that fiscal autonomy, without central political guidance, can produce "competition for rents" at the local level, as local governments fail to prevent extraction of rents from local firms. The analysis above may lead to the following implication: there are different sets of conditions under which fiscal autonomy (decentralization) can alternatively promote or inhibit local economic development. Our objective in this paper is to identify some of those conditions in the context of the Russian Federation.

\section{Decentralization and Regional Reform in Russia}

\subsection{Fiscal Federalism in the Russian Federation}

Fiscal federalism in the Russian Federation is characterized by a high level of de jure centralization, but a high level of de facto decentralization. Current rules strictly limit local powers to tax, and the adoption of the new Tax Code in 2000 limited potential sub-national taxes to a short list. Before 2000 all main taxes (VAT, personal and corporate income taxes, and excises) were shared between three levels of government. Overall, sub-national tax autonomy in Russia is much more limited than in such federations as Brazil, China, and India. Meanwhile, sub-national expenditures are also subject to rigid central regulations with respect to both the size and specific breakdown of particular spending items. In practice, however, fiscal policy is much more decentralized. The devolution of power to the Russian regions was primarily a response to a weakening central government following the collapse of the USSR, when it could no longer meet expenditure obligations (Lavrov 1996; Lavrov at al., 2001). Under these conditions, regions lobbied for greater autonomy through specific agreements with the center, while the federal government continued to limit its own expenditure responsibilities. Partly due to this "spontaneous" decentralization in the early 1990s, the actual degree of fiscal autonomy has varied across regions in the Russian Federation ever since. Through these agreements, regional governments have been afforded significant but uneven control over local tax and non-tax revenue, and over local spending needs.

In addition, under the Russian inter-governmental revenue sharing rules, shortfalls in regional expenditures are made up with transfers from the central government. Although formula-based in principle, in practice these arrangements have applied with much greater variability across regions due to two sets of factors. First, as there has been minimal constitutional elaboration of the revenue-sharing mechanism, the Russian system still lacks an adequate legal framework and stable, transparent rules for tax sharing, transfer allocation, and expenditure assignments. Instead of being based on ex-ante specified rules, inter-governmental finance in the Russian Federation is based on bargaining abilities of the individual regions (Freinkman, Treisman, and Titov 1999). During the 1990s, fiscal arrangements between regions and the center changed annually, as certain regions managed-through a combination of 
extortion and lobbying - to supplement their resources with additional funds from the federal government. Particularly culpable were the autonomous regions (see Figure 1), home to Russia's ethnic and linguistic minorities, whose governors often used the implicit threat of local Chechnya-style secessionist movements to squeeze greater sums from Moscow (Treisman 1999). To date, a large portion of the total transfer flow remains subject to regional lobbying (Sinelnikov et al. 2001). Furthermore, the current system of revenue sharing has fostered significant competition between the federal and sub-national authorities over the same taxable base. The effect of the competition over the same taxable base prompted regional and municipal authorities to increase their expenditure requirements (and thus enhance their bargaining positions) without expanding their respective tax base (Shleifer and Treisman 2000).

Second, at the sub-national level, the Russian environment for decentralization is characterized by wide opportunities for regions to decide almost unilaterally on specific budget sharing arrangements with municipalities (Freinkman and Yossifov 1999). Regional authorities have full discretion not merely for determining a desirable degree of centralization and redistribution of fiscal flows, but also for making frequent changes in the rules of the game. In such an environment, it is not surprising that a substantial cross-regional variation in actual decentralization patterns has emerged. Regions may experiment with more or less centralized schemes depending on their political preferences, specifics of economic structure, and social and geographical features. Regional disparities and discretion imply that incentive problems within Russia's regions (i.e. in region-city relations) are even more severe that those at the national level (center-regions).

In the second half of the 1990s the tax retention rate varied considerably across regions and from year to year (see Figure 2). Russian regions were permitted to keep, on average, two thirds of taxes raised within their territory. Although officially set at a common rate, retention rates varied more considerably due to several factors, including yearly changes in federal tax sharing rules, explicit exemptions granted to particular regions (e.g., Bashkortostan and Tatarstan), etc. In addition, different individual taxes (such as VAT, profit tax, and excises) were retained to differing degrees, and thus overall tax retention reflects, to some extent, different patterns of consumption and different production profiles across regions. Finally, the collection of different taxes tended to be differentially enforced: taxes that were "destined" to be shared with federal authorities were often allowed to go unpaid or be paid through non-cash settlements (barter and promisorry notes) while taxes to be retained were more likely to be collected on time and in cash, the overall result of which allowed a higher percentage of the "regional" portion of taxes to be collected while keeping a larger portion of "federal" taxes in arrears.

In some cases, regional governments granted enterprises outright exemptions from some local taxes. Several regions in Russia, including Gorny Altay, Kalmykia, and Ingushetia (regions with the lowest retention rates), followed a policy of massive tax exemptions combined with the informal agreements with enterprises that benefited from these exemptions on transferring a considerable portion of exempted taxes into regional extra-budgetary funds. As a result, these regions greatly reduced the size of their official budgets, while inflated an informal, off-budget share of their public finance system. These regions demonstrated the lowest level of actual retention, which somewhat underestimated the real level of taxes that remained under control of the respective regional governments. 
Figure 1. Autonomous Regions in the Russian Federation, 1996

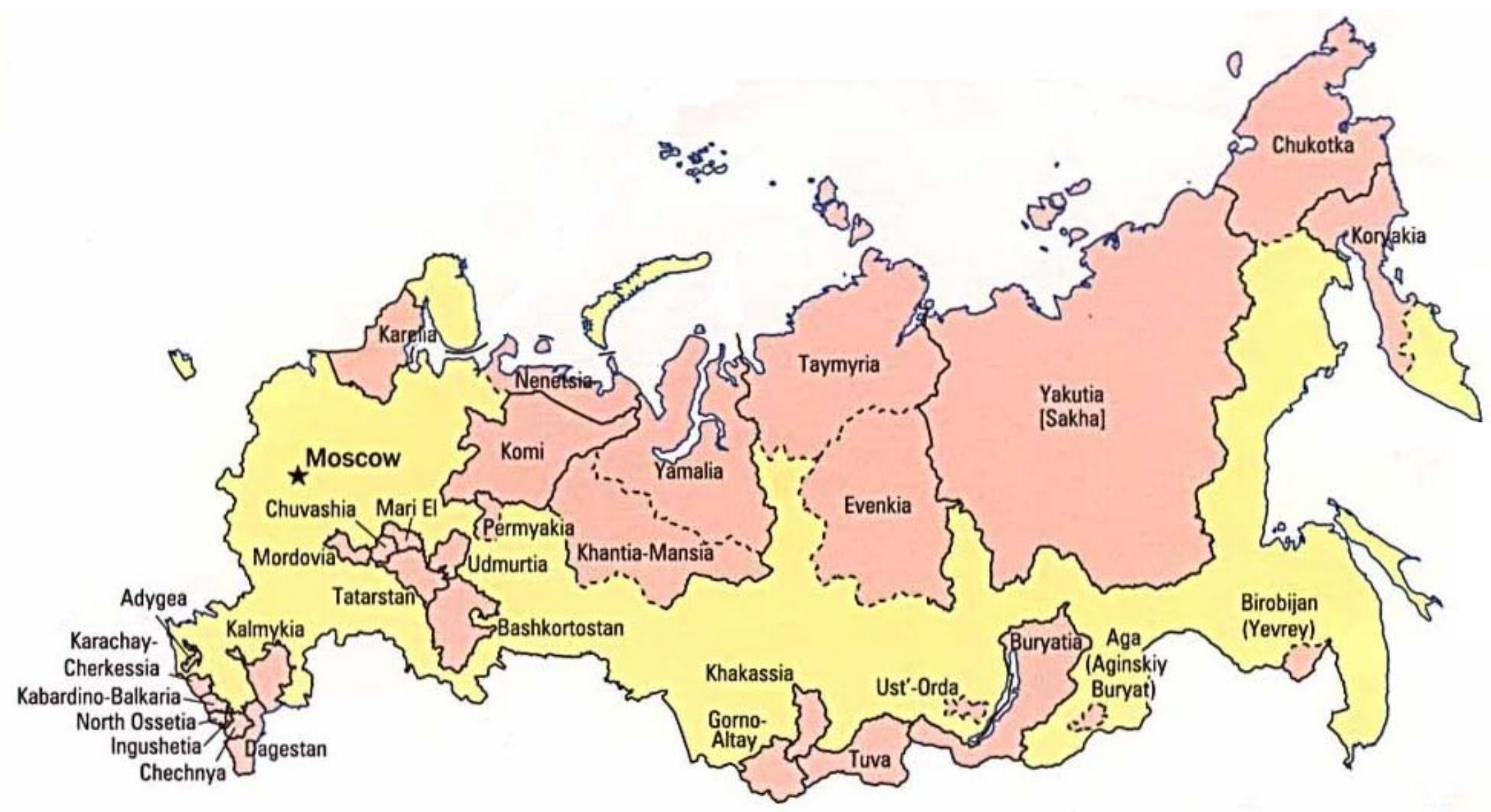

- Autonomous Republic boundary

- - - - Autonomous Okrug boundary

Source: http://www.lib.utexas.edu/maps/commonwealth/russia auton96.jpg 
Figure 2. Variation in Retention Rates across Russian Regions, 1996-1999

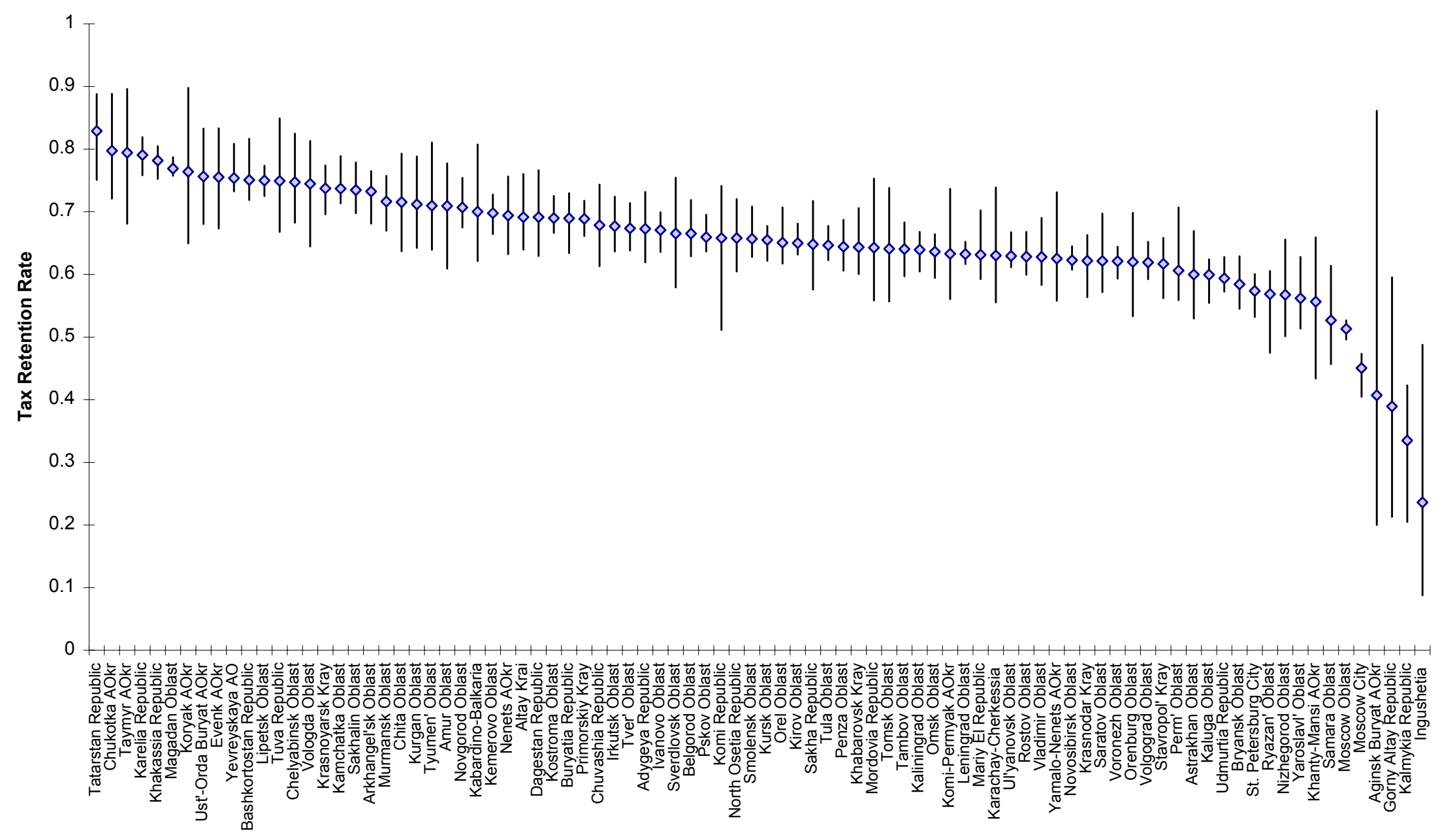


In 2000 the Russian government began a comprehensive reform of inter-governmental fiscal relations, including the elimination of all main distortions in the system, including clarification of expenditure assignments, expansion of local tax autonomy, elimination of the unfunded mandates, making the system of transfer allocations more transparent. Thus far, some progress has been achieved with respect to reforms of federal transfers. The new formula-based methodology for determining the transfer allocation from the main transfer window, the Equalization Fund, has helped concentrate federal resources in the poorest regions, has consolidated the entire transfer system, and has made it more predictable for recipients. The federal government has not, however, eliminated smaller but less transparent transfer channels (such as budget loans and mutual settlements), which remain outside of the Equalization Fund. In addition, the recent reforms considerably reduced the prevalence of tax sharing by turning VAT and part of exercises into the federal taxes.

\subsection{Regional Evidence}

Related research on the economic impact of regional fiscal policies in Russia has generally been divided on the subject of fiscal federalism. On the one hand, several empirical analyses have found that sub-national autonomy improves the economic performance of regions. Arhend (2000), for example, suggests that a dependence on federal transfers distorts regional governors' incentives: those who have a comparative advantage in getting transfers devote less effort into protecting their local tax base. Transfers come as a strongly negative factor in his growth regressions but this effect disappears when geographical and political factors are added. At the same time, Kuznetsova (2001) reports that there is no link between the incidence of subsidies in regional budgets and regional growth. A recent survey of 200 firms in 20 regions shows that local fiscal federalism arrangements - in particular, the extent to which additional local revenues are not taxed by the regional-level budgets - reduced the local regulatory costs of business (Center for Economic and Financial Research 2003).

On the other hand, several other analyses have found that fiscal autonomy has often enabled subnational governments to perpetuate soft-budget constraints for local enterprises. Recent evidence underscores the extent of this collusion. In a survey of over 800 public officials in the Russian regions, Stoner-Weiss finds that regional govermments have acquired significant autonomy from the center (often granted to mute secessionist tendencies), limiting the capacity of the central state to govern the provinces. But politicians and enterprise insiders in several of these regions have used their independence from Moscow to stall and reverse reforms, and to maintain local firms as sources of rents for both politicians and managers (Stoner-Weiss 2001).

Freinkman and Haney (1997) have shown that while explicit budget subsidies in subnational Russian budgets demonstrated a considerable cross-regional variation, on average about one third of total regional and municipal expenditures in the middle of the 1990s were linked to financing of various household and enterprise subsidies. The recipients of these benefits were concentrated in housing and utilities, transportation, agriculture, and they were among the largest region-specific companies. A McKinsey study (McKinsey \& Co. 1999) indicates that sub-national governments actively obstruct enterprise restructuring via the perpetuation of soft budget constraints, and in some cases through formal limitations on particular enterprise activities. Subsidies can take the form of preferential tax treatment, "discounts" on utility bills, and favored status in public procurement, all of which are intended to 
prevent companies from shutting down and laying off employees. This puts potentially productive companies at a cost disadvantage, blocking investments and growth on their part.

Similarly, Lavrov, Litwack, and Sutherland (2001) claim that complicated informal agreements between regional administrations and the largest local enterprises have been the general rule during the 1990s. Such enterprises are subject to implicit taxation in the form of mandatory financing of local public services - health, education, housing, road maintenance, etc. In return these firms receive various privileges, such as explicit and implicit tax exemptions, debt restructuring, and protection against bankruptcy and competition. (On the informality of mechanisms used by local government to influence local business, see Box 1). Finally, Radayev 1996) describes another type of the implicit subnational taxation in the form of forced "volunteer" contributions to various extra-budgetary funds, established through the sponsorship of subnational governments. Local SMEs, according to surveys, are facing a higher risk of being pressed to make a payment to such funds. While extra-budgetary funds are technically illegal, governments have been using indirect forms of control over the funds. Kuznetsova (2001) finds that the wealthier regions spend relatively more on subsidies to local enterprises, and more generally the regions with better endowments have been pursuing less efficient policies, for instance they have a higher tax burden, which hurts economic growth.

\section{Box 1. Inter-Governmental Finance and the Consequences for Business: The View from a Russian Town}

The city of Yaroslavl is a regional capital with a population of about 600 thousand, located approximately 200 miles north of Moscow. It derives a considerable share of its budget revenues from large privatized companies in oil processing and chemical industries. The municipality retains around $30 \%$ of the total amount of tax collected locally. This share was about $41-45 \%$ in the mid 1990 s but declined thereafter. Taxation of local businesses provides only $8-10 \%$ of the total municipal revenues.

Not unlike other subnational Russian governments, Yaroslavl has been intensively engaged in various local economic activities. Due to the existing federal legislation, the city does not have direct tax instruments at its disposal. It is using, however, alternative mechanisms, such as tax exemptions, restructuring of tax arrears, preferable access to real estate (office space) to increase revenues or decrease expenditures. The city preserves control over the local real estate market, finances most of new housing construction and owns about two thirds of the local office space. The municipal policy of highly subsidized rents and its refusal to privatize real estate is a significant source of advantages for incumbent businesses. The city also controls utility tariffs for major local utilities such as water and heating, and its policy of delayed tariff adjustments represents another instrument of defacto subsidization. Municipal policies are biased in favor of large state-owned or privatized enterprises and against new businesses. Both tax exemptions and tax restructuring are heavily concentrated in a limited number of large firms. While the government sponsors housing construction, no new construction firm has emerged during the 1990s; the market is completely dominated by the traditional recently privatized enterprises.

Small businesses in Yaroslav are subject to excessive administrative burdens, including numerous certification and licensing requirements, as well as a segmented system of business control and audit. There were 29 different agencies with authority for auditing local businesses: sanitary, architectural, construction inspections and the prosecutor's office were frequently mentioned as the worst offenders. To get connected to the local utility network is also considered expensive and time consuming, and frequently requires an intervention from the local government. Operations of most inspections are governed by federal legislation, which has been recently improved (new laws on registration, licensing and certification have been adopted in 2001 and 2002) and formally they are entirely outside of the local government's jurisdiction (see CEFIR 2003). In reality, however, the city has a considerable informal influence, and could negotiate with local representatives of federal agencies on behalf of local businessmen. The informal nature of such influence and interventions poses a risk of nepotism, non-transparency in business support, and eventually of collusion between officials and particular business groups.

Source: Author's interviews with Yaroslavl municipal governmental officials, June 2001. 
The previous analyses of variation in regional growth performance in the 1990s in Russia suggests that growth depends less on regional policies and much more on the initial industrial structure and regional endowments such as natural resources and human capital (Arhend 2000; Popov 2001). A large part of the observed differences in regional performance could be attributed to the "quality" of inherited industrial enterprises - the regions with a higher initial share of exports in the total industrial output, as well as shares of fuel, metals, and chemicals did significantly better than the rest. The resource endowments are also found to be among the main determinants of cross-regional income inequality (Dolinskaya 2001). Moreover, there is some evidence that in the middle of the 1990s, industrial growth was positively correlated with the regional income level (Freinkman and Yossifov 1999), i.e. regional incomes continued to diverge.

Nevertheless, little empirical analysis is available to confirm the existence of systematic distortions in incentives of Russian subnational governments. With the exception of Zhuravskaya (1999), who examines revenue sharing schemes between local and regional governments, most research is based on case studies of particular regions. Zhuravskaya found that Russian cities operate within a system of extreme fiscal discretion of regional governments, which has a negative impact on their efficiency in providing local public goods and infrastructure services. What has not been examined directly is the impact of fiscal decentralization on private sector development and variation in growth rates across regions.

\section{The Argument: Fiscal Federalism and Rentier Regions}

In the Russian regions, as is common in the transition economies, the prospects for economic growth are circumscribed by the problems of the "state-capture" economy, or the conditions under which large - usually former state-owned - enterprises have influenced the enactment of laws and policies through the provision of private benefits to public officials (Hellman, et al. 2000). Firms engage in this type of rent-seeking behavior in order to perpetuate the property-rights regime that restricts new entry into their markets, preserves their opportunities to arbitrage between reformed and unreformed parts of the regional economy, and protects them from regulatory interference by the central government. Regional governmental policies, in many cases, are characterized by this form of capture, where policies and regulations are enacted to the exclusive benefit of large formerly state-owned enterprises.

Yet, regional politicians are by no means pure "captives" of these firms, merely collecting private benefits (for example, in the form of campaign contributions) in exchange for their provision of favorable policies. On the contrary, they are typically active participants in a "symbiotic" relationship in which, through law, regulation, or intimidation, firms are forced to provide concrete political benefits to regional governments in the form of employment and nonwage benefits for both employees and the general public (Desai and Goldberg 2001). The absence of a well-functioning social safety net-either nationally or sub-nationally-has prompted regional governments to use firms as surrogate sources of social services. Russian regional governments have limited institutional experience with policy making in the public expenditure area, given the legacies of the Soviet state. In addition, post-Soviet Russian regions demonstrated close links between regional political elites and managers of largest regional companies. Thus, it is not entirely surprising that during the 1990s social policies of regional 
governments placed emphasis on subsidies and other support for specific sectors and individual companies, aimed at maintaining employment and reductions in local prices.

Our central claim in this paper is that the consequences of fiscal federalism depend upon the extent to which regional government-firm collusion and mutual rent seeking persist in any given region. Increased federal control over local finances may limit the variation in local economic and fiscal experiments, but it will also constrain rent seeking by rapacious regional governments and local firms.

\subsection{The Consequences of "Rentier" States}

We submit that the main incentives for these distortions derive from the "rentier" experiences in the Russian regions, and that the effect of fiscal autonomy on regional economic performance will depend, therefore, upon the types of these experiences. In a "rentier" economy, the public sector depends not on the domestic tax base but on externally generated revenues, or rents. Where income from these rents constitutes a significant portion of total government revenues, the rentiers will wield considerable political influence, and public officials will maintain themselves by appropriating these rents for public expenditures as well as for private use, and will face little incentive to expand the local tax base by cultivating the local business environment for two reasons.

First, a high degree of "unearned income" is likely to prompt more intense rent-seeking behavior among politicians whose incentives are influenced by the income streams to be gained from those income sources. Empirical assessments of this "voracity" thesis have shown that sudden terms-of-trade improvements, the new discovery of natural resources, or large stream of foreign aid can prompt a "gold rush" in which competition over newly available rents creates a diversion from more productive activities in the economy (Tornell and Lane 1999). Second, revenues from rent can lead to the "detachment" of public institutions from their tax base. As the income streams from rents become the primary source of public revenue, public institutions are more likely to become "predatory" in nature, relying less on sound, credibly-constrained tax policies, and more on the expropriation of these income streams (Levi 1988). Far from being a boon to the state, relief from the need to develop a sufficient local tax base leads to unaccountable, inefficient, and uninformed bureaucracies.

The economic and political consequences of rentierism are most commonly observed in the so-called "natural resource curse," but similar effects are found in countries that derive significant income in the form of remittances from foreign workers, or from foreign aid flows. Empirical analyses have shown that resource-abundant countries have historically had lower growth rates than economies with fewer resources (Sachs and Warner 2001) and tend to be governed by more corrupt, less democratic polities (Leite and Weidmann 1999; Ross 2001). Chaudhury demonstrates how states relying on either natural resource income or the remittance income of foreign workers tend to have weak institutions of public expenditure management (Chaudhry 1997). Where the sources of public revenue are few and concentrated, there are especially strong incentives for collusion between the state and those who control income sources in order to maintain the status quo (Moore 1998). Moreover, since natural resource endowments represent immobile or "specific" assets, rents from these assets are more readily captured by local elites than in the case of more mobile assets (Collier 2001). Recent 
assessments, moreover, have also shown that foreign aid flows create similar adverse incentives for public officials in aid-dependent countries. ${ }^{1}$

\subsection{Resource Wealth and Budgetary Transfers in the Russian Context}

Of particular importance to the experience of Russian regions are two major "rentable" sources of income: (i) revenues from the production and export of natural resources; ${ }^{2}$ and (ii) revenues from budgetary transfers from the central government. At the Russian sub-national level, potential resource rents are, of course, largest in the oil, gas, and mineral-rich regions, where privately owned resource companies provide significant private benefits to politicians and significant non-wage benefits to the local population. Indeed, the Russian government is generally believed to under-tax the country's major energy and fuel companies. ${ }^{3}$ Consequently, a relatively small fraction of natural resource rents are captured by the public sector in the Russian Federation; rather, most of these rents are appropriated by the private interests that control the natural-resource firms (Esanov, Raiser, and Buiter 2001).

Transfers, on the other hand, are primarily a reflection of the central government's efforts to reduce cross-regional income differences through redistribution to the poorer regions. For the transfer-dependent regions it is typical to have large amounts of social liabilities and the depressed enterprise sector, which undertook little of post-socialist restructuring. The largest ultimate beneficiaries of federal transfers in these regions are often the large loss-making firms - typically voucher-privatized and/or partially state-owned firms requiring some form of budget subsidy for their continued survival. Such enterprises remain the largest local employers, and are run by manager-owners who, with the support of regional governments, have shielded their firms from competition. Thus, the collusion between poor regional administrations and managers of bankrupt enterprises is to a large extent funded from the federal budget through the intergovernmental transfer system. In other words, local coalitions in support of the status quo have been strengthened by the acquisition and distribution on federal transfers among local constituents.

Since the higher the tax retention rate the more costly is a loss of tax revenue from preserving un-restructured enterprises, higher retention rates should have, ceteris paribus, a positive effect on incentives to restructure, and thus on regional economic performance. We argue, however, that where external income streams are provided, incentives for collusion between large enterprises and regional governments could undermine the positive effect of fiscal

\footnotetext{
${ }^{1}$ Excessive dependence on foreign aid makes national governments less financially dependent on their own taxpayers and can thus generate similar incentive distortions as do natural resource rents: respective governments would find it more efficient to spend more resources on extracting additional aid from the international community than on developing their own tax base (Moore 1998). Similarly, cross-national evidence also suggests that foreign aid can erode the quality of borrowing governmental institutions (Knack 2000).

2 Similar rent incomes are also available to regional elites in cases when large highly profitable firms (e.g. metallurgical plants) were established in their regions before the transitions through a system of investment grants funded by the USSR budget. When such firms become a dominant source of regional budget revenues, their role is not much different from major oil and gas extracting companies in the resource abundant regions.

3 The Russian Federation in 2000, for example, generated approximately one-half of the tax revenues per ton of extracted oil of that of the OECD oil producers, Denmark, Norway, and U.K. (Speck and Matusevich 2002).
} 
autonomy. Under these circumstances, we would expect increased revenue retention to create stronger incentives for local economic growth the more likely it is that local governments do not face incentive distortions deriving from large potential rents to be captured. If these distractions do exist, increased fiscal autonomy may encourage local government agencies to compete for rents, collude with the owners of major local firms, while doing very little to improve the business environment for the rest of the local economy. In the regions with more limited rent seeking opportunities, fiscal autonomy is more likely to promote economic growth and recovery. But fiscal autonomy granted to natural-resource abundant regions or transfer-dependent regions is likely to exacerbate this competition-for-rents problem, and is therefore likely to erode the growth effects of fiscal autonomy.

We seek to explain variation in economic performance across Russian regions, and determine the influence of fiscal arrangements on this performance. The study intends to quantify a scale of incentive problems that affect policies of sub-national governments. As such, we are interested primarily in the consequences of the fiscal autonomy on regional growth. We seek to test the governing hypothesis that fiscal autonomy will have a positive effect of growth rates, but that effect will be decreasing as the share of local revenue derived from "rentable" sources - revenues from extracting and exporting natural resources and from inter-governmental transfers-increases.

\section{$3 \quad$ Data and Results}

\subsection{Variables and Single-Equation Specification}

Our base sample includes data from 80 Russian regions between 1996 and 1999. ${ }^{4}$ We also estimated our models for smaller more homogeneous samples of Russian regions as described below. The most of regional data have been provided by the Russian Federation's State Committee for Statistics (Roskomstat). The fiscal data, including those on retention rates and inter-governmental transfers, were provided by the Moscow Center for Fiscal Policy, which generated these indicators based on the original database of the Russian Ministry of Finance.

\footnotetext{
4 The sample excluded the Chechen Republic, and eight Authonomus Okrugs, which are the smallest Russian regions with limited statistical coverage.
} 
We seek to explain cross-regional variation in regional growth based on regression analysis of regional data. Our basic regressions take the following form:

$$
y_{i t}=\beta_{0}+\beta_{1} \mathbf{X}_{i t}+\beta_{2} R_{\mathrm{it}}+\beta_{3} Q_{\mathrm{it}}+\beta_{4}(R \times Q)_{i t}+\varepsilon_{i t}
$$

where $y_{i t}=Y_{t} / Y_{1990}{ }^{5}$ and $Y$ is industrial output of the $i^{\text {th }}$ region, deflated by the regional price deflator. $\mathbf{X}$ is a vector of control variables, $\mathrm{R}$ the tax retention rate, $\mathrm{Q}$ a measure of "rents" from non-tax revenue, and $\varepsilon$ is a random disturbance, for regions $\mathrm{i}=1, \ldots, \mathrm{N}$, and for years $\mathrm{t}=1996$ 1999. We use a cumulative measure of output collapse rather than annual changes in gross regional product for two reasons. First, as the output recovery index measures accumulated, longer-term changes in regional development, rather than annual changes in the regional economy, the recovery index is less affected by idiosyncratic, year-to-year fluctuations in regional incomes due to, e.g., the impact of the Russian financial crisis, changes in commodity prices (for natural resource-dependent regions), etc. Second, the output recovery measure carries much greater cross-regional variation than annual change in gross regional product. The initial major shock of 1991-93 affected regions quite differently based on their production profile and other initial conditions, and different regional rates of after-shock recovery increases crossregional variation in cumulative output decline. Our industry-focused recovery index underestimates the rate of economic recovery in agricultural and other regions with the less developed industrial sector. In our statistical analysis below we control for a possible bias, related to such a feature of our dependent variable, by running a separate set of regressions for a more homogeneous sub-sample of the regions that constitute an industrial core of Russia.

We examine the effect of two different sources of rents: natural resource production and transfers from the federal budget. The former (Resources) is proxied by the percentage of regional industrial output that derives from "fuel and energy" production, according to the Roskomstat classification. The latter is the share of regional budget revenues from federal transfers (Transfers). ${ }^{6}$ Our Transfers variable includes all main channels through which federal funds were transferred to regions, i.e. it reflects, in addition to the largest program of equalization transfers, smaller federal programs, such as e.g. budget subventions. Both variables Transfers and Resources show a high degree of variation in the Russian context, with the coefficient of variation (ratio of standard deviation and mean) exceeding $70 \%$ in both cases. While for the whole sample the non-weighted average share of energy sector in the industrial output was about $20 \%$, for 31 regions this share exceeded one third. Similarly, while the average Russian region received $16 \%$ of its revenues through federal transfers, for 18 regions this share

\footnotetext{
5 This "recovery index" reflects how much of the pre-reform level of industrial output was recovered by the second part of the 1990s. It would be preferable, of course, to calculate longer-term recovery (and growth) rates based on annual changes in gross regional product. No data for gross regional product exist, however, for any years before 1996, and thus industrial output is our chosen measure.

${ }^{6}$ Our regional budget variables relate to the consolidated regional budget that covers both the budget of regional governments and budgets of municipalities located within the region.
} 
was above one third. Among the control variables we consider are a proxy for human capital endowment, the number of university-educated students per 10,000 persons (University), local subsidies as a percentage of regional budgetary expenditures (Subsidies), to control for local wealth, household expenditures per capita (Household Expenditures), and the log of the regional population (Population) to control for size. We also include three administrative-status dummy variables, Republic, Okrug, and City, to control for the differential impact of autonomous regions as well as of the large cities (i.e., Moscow and St. Petersburg).

As mentioned, our measure of fiscal incentives is the tax revenue retention rate (Retention), or the share of locally generated revenues kept with the regional budget. It should be noted that this variable reflects only official taxes, collected and accounted in regular government budgets. Because of the high incidence of informal regional taxation that remains off-budget, our retention indicator underestimates the degree of regional control over the local tax base. We are interested, however, in the impact of inter-governmental fiscal arrangements on regional incentives to support growth. It is likely that revenues hidden from the federal government outside of the regular regional budget would have quite a limited impact on "growth incentives" because of unstable, temporary nature of such a diversion of budget resources. Large extra-budgetary funds (EBFs) could help regions to solve particular current budget or economic problems, but their incentive effect if any would be negative: regions with large EBFs would be more inclined to invest their resources in diverting tax revenues from the formal to informal system of public finance, and less be concerned about an expansion in the local tax base.

Descriptive statistics for all variables used in main regressions in this paper are listed in Table 1. ${ }^{7}$ Region-by-region averages for all variables are presented in Table 2. Given regional price variation in Russia, we deflated regional and household income variables using annual average regional costs of a minimum consumer basket as a deflator. Finally, we include year dummies in all regressions to control for unobserved time effects - particularly important in the years 1998 and 1999 following the ruble devaluation and the fiscal and monetary adjustments that followed. We estimate the regression equation using OLS with panel-corrected standard errors (OLS-PCSE) to control for contemporaneous correlation of the errors as suggested by Beck and Katz (Beck and Katz 1995; Beck and Katz 1996).

\subsection{Basic Results}

Basic regression results are presented in Table 3. The first two columns report OLSPCSE results using the full sample of observations. Column one reports results from a base regression equation without interactive terms. In addition to university, expenditure, and subsidy variables, we include three administrative-status dummies to control for any unexplained differences in growth rates across autonomous republics, okrugs, and the two metropolitan areas that have oblast status, Moscow and St. Petersburg. The retention rate coefficient carries the

\footnotetext{
${ }^{7}$ We also considered in our model a wide range of other control variables that reflect different demographic, social, and industrial characteristics of the regions, such as e.g. age structure, share of urban population, R\&D employment, availability of housing, etc. However, all such variables proved to be statistically insignificant.
} 
expected positive sign, and the growth effect of regional natural resource wealth is similarly positive. Additionally, the positive sign on the republic dummy indicates higher growth rates among the autonomous republics.

Table 1. Descriptive Statistics of Variables Included in Regressions

\begin{tabular}{rrrrrrrr}
\hline Variable & Mean & $\begin{array}{r}\text { Std. } \\
\text { Dev }\end{array}$ & Min. & Max. & N & $\begin{array}{r}\text { T } \\
\text { (max.) }\end{array}$ & Obs. \\
\hline Recovery Index & 0.44 & 0.16 & 0.10 & 1.07 & 87 & 4 & 348 \\
University & 171.82 & 84.99 & 2.00 & 652.00 & 81 & 4 & 322 \\
Household Expenditure & 1.43 & 0.89 & 0.20 & 9.22 & 88 & 4 & 343 \\
Subsidies & 0.19 & 0.31 & 0.00 & 4.76 & 88 & 4 & 351 \\
Retention & 0.65 & 0.11 & 0.09 & 0.90 & 88 & 4 & 352 \\
Resources & 29.71 & 21.62 & 0.80 & 98.00 & 87 & 2 & 174 \\
Transfers & 0.21 & 0.16 & 0.00 & 0.86 & 88 & 4 & 352 \\
Population & 6.94 & 1.20 & 2.89 & 9.0 & 88 & 4 & 352 \\
Republic & 0.24 & 0.43 & 0.00 & 1.00 & 88 & 4 & 352 \\
Okrug & 0.11 & 0.32 & 0.00 & 1.00 & 88 & 4 & 352 \\
City & 0.02 & 0.15 & 0.00 & 1.00 & 88 & 4 & 352 \\
\hline
\end{tabular}

In the second specification, we add the interactive term. The sign on the retention coefficient remains positive and significant and the resources coefficient also carries a positive, significant sign, suggesting a positive relationship between natural resource wealth and regional growth. The negative sign on the interactive term however, indicates that the effect of fiscal autonomy is decreasing in natural resource wealth, as hypothesized. Note that, in the full sample with the interactive term included, republics and okrugs are less likely to have experienced output recovery, while Moscow and St. Petersburg are more likely to have recovered. Larger regions are also associated with greater recovery rates. Note that regions with greater household wealth, moreover, are also positively associated with output recovery, suggesting that regional incomes have diverged since the early 1990s. Finally, AR(1) tests do not yield large rho values, and the errors from this estimation do not appear to exhibit the kind of serial correlation often found in growth regressions.

The robustness of these results is confirmed through two adjustments to this basic estimation. First, we eliminate okrugs and the municipalities of Moscow and St. Petersburg from our sample and re-run the estimation without these regions. ${ }^{8}$ Second, we rerun the specification on a more homogeneous set of 50 "industrial core" regions-mainly excluding the North Caucasus and Asian autonomous regions from the sample. In both instances, the previous findings hold: retention and resource coefficients are linearly positive but their combined effect is negative, although the interactive effect is not longer significant in the most constrained sample.

\footnotetext{
${ }^{8}$ Given the availability of data for the base sample, this simply eliminates Chukotka Okrug and two capital cities, reducing our number of cross-sections by three units.
} 
Table 2. Russian Regions: Basic Indicators (1996-1999 Averages)

\begin{tabular}{|c|c|c|c|c|c|c|c|}
\hline Region Name & $\begin{array}{c}\text { Admin. } \\
\text { Status }\end{array}$ & $\begin{array}{c}\text { Indust. } \\
\text { Core } \\
\text { Region }\end{array}$ & $\begin{array}{c}\text { Population } \\
\text { (thousands) }\end{array}$ & $\begin{array}{l}\text { Resource } \\
\text { Production }\end{array}$ & $\begin{array}{c}\text { Tax } \\
\text { Retention } \\
\text { Rate }\end{array}$ & $\begin{array}{l}\text { Budgetary } \\
\text { Transfers }\end{array}$ & $\begin{array}{c}\text { Cumulative } \\
\text { Output } \\
\text { Recovery }\end{array}$ \\
\hline Adygeya Republic & 2 & & 450 & 6.1 & 67.3 & 45.8 & 39.9 \\
\hline Aginsk Buryat AOkr & 3 & & 79 & & & 69.8 & 15.9 \\
\hline Altay Krai & 1 & & 2,667 & 20.5 & 69.2 & 31.2 & 35.7 \\
\hline Amur Oblast & 1 & & 1,019 & 48.3 & 70.9 & 33.5 & 31.4 \\
\hline Arkhangel'sk Oblast & 1 & $\mathrm{~T}$ & 1,485 & 23.7 & 73.2 & 13.6 & 67.7 \\
\hline Astrakhan Oblast & 1 & $\mathrm{~T}$ & 1,027 & 60.8 & 60.0 & 24.1 & 71.4 \\
\hline Bashkortostan Republic & 2 & $\mathrm{~T}$ & 4,113 & 48.4 & 75.1 & 1.4 & 57.7 \\
\hline Belgorod Oblast & 1 & $\mathrm{~T}$ & 1,488 & 10.5 & 66.5 & 6.6 & 83.2 \\
\hline Bryansk Oblast & 1 & $\mathrm{~T}$ & 1,460 & 10.4 & 58.4 & 20.7 & 30.8 \\
\hline Buryatia Republic & 2 & & 1,043 & 46.9 & 68.9 & 28.6 & 56.8 \\
\hline Chuvashia Republic & 2 & $\mathrm{~T}$ & 1,359 & 16.3 & 67.9 & 15.6 & 32.7 \\
\hline Chelyabinsk Oblast & 1 & $\mathrm{~T}$ & 3,679 & 13.4 & 74.7 & 6.9 & 41.8 \\
\hline Chita Oblast & 1 & & 1,273 & 45.6 & 71.5 & 23.2 & 27.9 \\
\hline Chukotka AOkr & 3 & & 79 & 44.5 & 79.7 & 40.7 & 38.6 \\
\hline Dagestan Republic & 2 & & 2,110 & 43.0 & 69.1 & 52.5 & 16.6 \\
\hline Evenk $A O k r$ & 3 & & 19 & & & 46.4 & 19.3 \\
\hline Gorny Altay Republic & 2 & & 203 & & & 45.7 & 34.6 \\
\hline Ingushetia & 2 & & 357 & 82.2 & 23.6 & 51.1 & \\
\hline Irkutsk Oblast & 1 & & 2,768 & 25.7 & 67.7 & 5.6 & 52.3 \\
\hline Ivanovo Oblast & 1 & $\mathrm{~T}$ & 1,240 & 22.4 & 67.1 & 28.5 & 25.0 \\
\hline Kabardino-Balkaria & 2 & & 792 & 21.0 & 70.0 & 44.9 & 30.9 \\
\hline Kaluga Oblast & 1 & $\mathrm{~T}$ & 1,090 & 14.9 & 59.9 & 26.1 & 48.1 \\
\hline Kaliningrad Oblast & 1 & $\mathrm{~T}$ & 945 & 27.5 & 63.9 & 9.2 & 28.8 \\
\hline Kamchatka Oblast & 1 & & 393 & 21.3 & 73.7 & 31.1 & 40.3 \\
\hline Karelia Republic & 2 & $\mathrm{~T}$ & 774 & 10.7 & 79.1 & 14.4 & 56.0 \\
\hline Kalmykia Republic & 2 & & 317 & 71.5 & 33.5 & 45.9 & 23.4 \\
\hline Karachay-Cherkessia & 2 & & 436 & 14.2 & 63.0 & 38.6 & 23.1 \\
\hline Kemerovo Oblast & 1 & $\mathrm{~T}$ & 3,015 & 42.6 & 69.8 & 14.0 & 57.9 \\
\hline Khabarovsk Kray & 1 & & 1,539 & 31.3 & 64.4 & 16.9 & 32.6 \\
\hline Khakassia Republic & 2 & & 583 & 25.6 & 78.2 & 11.6 & 65.7 \\
\hline Khanty-Mansi AOkr & 3 & & 1,358 & & & 1.2 & 59.6 \\
\hline Kirov Oblast & 1 & $\mathrm{~T}$ & 1,607 & 15.5 & 65.0 & 18.2 & 44.3 \\
\hline Komi-Permyak AOkr & 2 & $\mathrm{~T}$ & 1,155 & & & 6.7 & 54.4 \\
\hline Komi Republic & 3 & & 154 & 8.3 & 65.8 & 45.4 & 65.4 \\
\hline Koryak AOkr & 3 & & 31 & & & 36.5 & 38.6 \\
\hline Kostroma Oblast & 1 & $\mathrm{~T}$ & 794 & 35.8 & 69.0 & 29.0 & 39.6 \\
\hline Krasnodar Kray & 1 & $\mathrm{~T}$ & 5,071 & 22.2 & 62.2 & 16.1 & 55.7 \\
\hline Krasnoyarsk Kray & 1 & & 3,069 & 12.8 & 73.7 & 2.2 & 62.0 \\
\hline Kursk Oblast & 1 & $\mathrm{~T}$ & 1,331 & 26.8 & 65.5 & 12.6 & 63.9 \\
\hline Kurgan Oblast & 1 & $\mathrm{~T}$ & 1,103 & 22.2 & 71.2 & 23.1 & 34.4 \\
\hline Leningrad Oblast & 1 & $\mathrm{~T}$ & 1,679 & 37.4 & 63.3 & 6.2 & 56.3 \\
\hline Lipetsk Oblast & 1 & $\mathrm{~T}$ & 1,246 & 10.9 & 75.0 & 1.5 & 63.8 \\
\hline Magadan Oblast & 1 & & 243 & 24.5 & 76.9 & 26.8 & 58.7 \\
\hline Mariy El Republic & 2 & $\mathrm{~T}$ & 762 & 21.1 & 63.1 & 27.2 & 40.4 \\
\hline Moscow Oblast & 1 & $\mathrm{~T}$ & 6,550 & 11.9 & 51.3 & 5.7 & 39.2 \\
\hline
\end{tabular}




\begin{tabular}{|c|c|c|c|c|c|c|c|}
\hline Mordovia Republic & 2 & $\mathrm{~T}$ & 941 & 13.1 & 64.3 & 31.6 & 36.9 \\
\hline Moscow City & 4 & & 8,632 & 16.6 & 45.0 & 3.1 & 42.4 \\
\hline Murmansk Oblast & 1 & $\mathrm{~T}$ & 1,008 & 18.0 & 71.7 & 21.2 & 65.3 \\
\hline Nenets AOkr & 3 & & 47 & & & 21.7 & 106.6 \\
\hline Nizhegorod Oblast & 1 & $\mathrm{~T}$ & 3,687 & 10.8 & 56.7 & 4.9 & 57.1 \\
\hline North Osetia Republic & 2 & & 667 & 15.1 & 65.8 & 43.9 & 35.9 \\
\hline Novosibirsk Oblast & 1 & $\mathrm{~T}$ & 2,748 & 19.2 & 62.3 & 8.9 & 39.8 \\
\hline Novgorod Oblast & 1 & $\mathrm{~T}$ & 736 & 11.8 & 70.7 & 24.6 & 60.7 \\
\hline Omsk Oblast & 1 & $\mathrm{~T}$ & 2,173 & 34.3 & 63.6 & 11.4 & 38.4 \\
\hline Orenburg Oblast & 1 & $\mathrm{~T}$ & 2,228 & 51.0 & 62.0 & 16.9 & 55.0 \\
\hline Orel Oblast & 1 & $\mathrm{~T}$ & 905 & 14.2 & 65.1 & 18.3 & 47.5 \\
\hline Penza Oblast & 1 & $\mathrm{~T}$ & 1,544 & 18.9 & 64.4 & 23.7 & 35.6 \\
\hline Perm' Oblast & 1 & $\mathrm{~T}$ & 2,982 & 31.0 & 60.6 & 4.1 & 61.1 \\
\hline Primorskiy Kray & 1 & & 2,206 & 24.7 & 68.9 & 24.0 & 50.3 \\
\hline Pskov Oblast & 1 & $\mathrm{~T}$ & 815 & 19.9 & 65.9 & 35.0 & 30.5 \\
\hline Rostov Oblast & 1 & $\mathrm{~T}$ & 4,392 & 30.5 & 62.8 & 17.6 & 41.0 \\
\hline Ryazan' Oblast & 1 & $\mathrm{~T}$ & 1,301 & 41.8 & 56.8 & 16.8 & 38.0 \\
\hline Sakha Republic & 1 & & 615 & 48.0 & 64.8 & 25.1 & 53.8 \\
\hline Sakhalin Oblast & 2 & & 996 & 22.1 & 73.5 & 22.0 & 79.6 \\
\hline Samara Oblast & 1 & $\mathrm{~T}$ & 3,306 & 16.7 & 52.7 & 1.8 & 63.4 \\
\hline Saratov Oblast & 1 & $\mathrm{~T}$ & 2,721 & 33.1 & 62.1 & 16.5 & 45.6 \\
\hline Smolensk Oblast & 1 & $\mathrm{~T}$ & 1,151 & 23.0 & 65.7 & 13.4 & 53.0 \\
\hline Stavropol' Kray & 1 & $\mathrm{~T}$ & 2,684 & 34.7 & 61.7 & 22.1 & 41.5 \\
\hline St. Petersburg City & 4 & & 4,738 & 10.3 & 57.4 & 2.3 & 35.1 \\
\hline Sverdlovsk Oblast & 1 & $\mathrm{~T}$ & 4,645 & 13.5 & 66.5 & 2.7 & 37.3 \\
\hline Tambov Oblast & 1 & $\mathrm{~T}$ & 1,286 & 18.6 & 64.0 & 20.9 & 53.4 \\
\hline Tatarstan Republic & 2 & $\mathrm{~T}$ & 3,775 & 45.6 & 82.9 & 2.1 & 75.7 \\
\hline Taymyr AOkr & 3 & & 44 & & & 19.2 & 40.7 \\
\hline Tomsk Oblast & 1 & $\mathrm{~T}$ & 1,072 & 38.7 & 64.1 & 11.0 & 64.5 \\
\hline Tula Oblast & 1 & $\mathrm{~T}$ & 1,776 & 14.6 & 64.7 & 17.0 & 47.7 \\
\hline Tuva Republic & 2 & & 311 & 36.8 & 74.9 & 49.2 & 36.0 \\
\hline Tver' Oblast & 1 & $\mathrm{~T}$ & 1,625 & 32.5 & 67.4 & 17.2 & 39.7 \\
\hline Tyumen' Oblast & 1 & & 3,210 & 93.2 & 71.0 & 7.4 & 62.5 \\
\hline Udmurtia Republic & 2 & $\mathrm{~T}$ & 1,636 & 31.1 & 59.4 & 16.2 & 41.0 \\
\hline Ul'yanovsk Oblast & 1 & $\mathrm{~T}$ & 1,480 & 16.0 & 63.0 & 12.4 & 77.5 \\
\hline Ust'-Orda Buryat AOkr & 3 & & 144 & & & 50.1 & 28.1 \\
\hline Vladimir Oblast & 1 & $\mathrm{~T}$ & 1,625 & 15.3 & 62.8 & 18.5 & 44.2 \\
\hline Vologda Oblast & 1 & $\mathrm{~T}$ & 1,335 & 8.5 & 74.5 & 6.6 & 73.6 \\
\hline Volgograd Oblast & 1 & & 2,694 & 29.4 & 61.9 & 10.9 & 36.2 \\
\hline Voronezh Oblast & 1 & $\mathrm{~T}$ & 2,480 & 21.4 & 62.1 & 15.9 & 37.9 \\
\hline Yamalo-Nenets AOkr & 3 & & 496 & & & 0.7 & 71.2 \\
\hline Yaroslavl' Oblast & 1 & $\mathrm{~T}$ & 1,430 & 27.0 & 56.2 & 9.7 & 41.2 \\
\hline Yevreyskaya AO & 2 & & 204 & 24.3 & 75.4 & 42.8 & 11.4 \\
\hline Sample Averages & & & 1,687 & 29.7 & 65.2 & 21.2 & 44.3 \\
\hline
\end{tabular}

Source: State Committee for Statistics, and Ministry of Finance, Russian Federation.

Notes: Administrative status: 1 = oblast; $2=$ republic; $3=$ okrug, $4=$ city. All averages are for 1996-1999 and are expressed in percentages, except where noted. Resource production is share of fuel and energy production in regional output. Transfers are budgetary transfers as percentage of regional governmental revenue. Cumulative recovery is 1999 industrial output as a percentage of 1990 industrial output. 
Table 3. Natural Resource Wealth and Regional Output Recovery: Basic Regression Results

\begin{tabular}{|c|c|c|c|c|}
\hline & \multicolumn{4}{|c|}{ OLS with Panel-Corrected Standard Errors } \\
\hline & $\begin{array}{c}\text { Full Sample } \\
\text { (1) }\end{array}$ & $\begin{array}{c}\text { Full Sample } \\
\text { (2) }\end{array}$ & $\begin{array}{c}\text { Cities \& Okrugs } \\
\text { Excluded } \\
\text { (3) } \\
\end{array}$ & $\begin{array}{c}\text { Industrial } \\
\text { Core } \\
(4) \\
\end{array}$ \\
\hline University & $\begin{array}{l}-0.0001 \\
(0.0001)\end{array}$ & $\begin{array}{l}-0.0001 \\
(0.0001)\end{array}$ & $\begin{array}{l}-0.0001 \\
(0.0001)\end{array}$ & $\begin{array}{l}0.0000 \\
(0.0001)\end{array}$ \\
\hline $\begin{array}{l}\text { Household } \\
\text { Expenditures }\end{array}$ & $\begin{array}{l}0.0534 * * * \\
(0.0135)\end{array}$ & $\begin{array}{l}0.0532 * * * \\
(0.0138)\end{array}$ & $\begin{array}{l}0.1319^{* * * *} \\
(0.0363)\end{array}$ & $\begin{array}{l}0.0986^{* * * *} \\
(0.0354)\end{array}$ \\
\hline Subsidies & $\begin{array}{l}-0.0028 \\
(0.0144)\end{array}$ & $\begin{array}{l}0.0022 \\
(0.0140)\end{array}$ & $\begin{array}{l}0.0095 \\
(0.0463)\end{array}$ & $\begin{array}{l}-0.0435 \\
(0.0692)\end{array}$ \\
\hline Retention & $\begin{array}{l}0.4057 * * * \\
(0.1033)\end{array}$ & $\begin{array}{l}0.5298 * * * \\
(0.1393)\end{array}$ & $\begin{array}{l}0.6266 * * \\
(0.2579)\end{array}$ & $\begin{array}{l}0.6633 * * * \\
(0.2330)\end{array}$ \\
\hline Resources & $\begin{array}{l}0.0009 * * * \\
(0.0003)\end{array}$ & $\begin{array}{l}0.0031 * * * \\
(0.0010)\end{array}$ & $\begin{array}{l}0.0052 * \\
(0.0029)\end{array}$ & $\begin{array}{l}0.0068 * \\
(0.0039)\end{array}$ \\
\hline Retention $\times$ Resources & & $\begin{array}{l}-0.0036 * * \\
(0.0014)\end{array}$ & $\begin{array}{l}-0.0068 * \\
(0.0039)\end{array}$ & $\begin{array}{l}-0.0093 \\
(0.0060)\end{array}$ \\
\hline Population & $\begin{array}{l}0.0197 * * * \\
(0.0043)\end{array}$ & $\begin{array}{l}0.0216^{* * *} \\
(0.0038)\end{array}$ & $\begin{array}{l}0.0060 \\
(0.0070)\end{array}$ & $\begin{array}{l}-0.0061 \\
(0.0112)\end{array}$ \\
\hline Republic & $\begin{array}{l}-0.0283 * * * \\
(0.0044)\end{array}$ & $\begin{array}{l}-0.0288 * * * \\
(0.0041)\end{array}$ & $\begin{array}{l}-0.0096 \\
(0.0106)\end{array}$ & $\begin{array}{l}-0.0018 \\
(0.0105)\end{array}$ \\
\hline Okrug & $\begin{array}{l}-0.2347 * * * \\
(0.0384)\end{array}$ & $\begin{array}{l}-0.2290 * * * \\
(0.0393)\end{array}$ & & \\
\hline City & $\begin{array}{l}0.0447^{*} \\
(0.0242)\end{array}$ & $\begin{array}{l}0.0611^{* *} \\
(0.0236)\end{array}$ & & \\
\hline Obs & 311 & 311 & 293 & 201 \\
\hline$N$ & 80 & 80 & 75 & 51 \\
\hline$R^{2}$ & 0.2030 & 0.2059 & 0.2239 & 0.1517 \\
\hline $\begin{array}{l}\text { Wald } \chi^{2} \\
(\text { prob. }) \\
\text { F-Test } \\
(\text { prob. })\end{array}$ & $\begin{array}{l}1428.9 \\
(0.0000)\end{array}$ & $\begin{array}{l}1673.01 \\
(0.0000)\end{array}$ & $\begin{array}{l}168.42 \\
(0.0000)\end{array}$ & $\begin{array}{l}12.8 \\
0.0771\end{array}$ \\
\hline$\rho$ & & 0.1987 & 0.1345 & -0.0205 \\
\hline
\end{tabular}

Notes: Dependent variable is annual growth in gross regional product. Estimation is performed using OLS with errors corrected for contemporaneous correlation across panels. Panel-corrected standard errors are in parentheses. Time dummies are included in all regressions. Coefficients on time dummies and intercepts are not reported.

The extraction of natural resources and budgetary transfers from the central government serve similar fiscal functions, namely, they allow sub-national authorities to raise funds without increased reliance on broadening the tax base and improvements in tax collection. Table 4, therefore, replaces the natural-resource wealth indicator with a measure of transfers. The signs on the relevant coefficients are as expected. Tax retention rates are positively correlated with cumulative recovery. The linear effect of budgetary transfers on regional recovery is positive (initially significant, although not in the latter two specifications). The interactive term, again, carries a strongly significant, negative sign. Moreover, the magnitude of the coefficient on the 
interactive term is larger than that of the linear retention rate, suggesting that the net effect of increasing both the tax retention rate and the transfer ratio has a negative effect on regional recovery.

Table 4. Budgetary Transfers and Regional Output Recovery: Basic Regression Results

\begin{tabular}{|c|c|c|c|c|}
\hline & \multicolumn{4}{|c|}{ OLS with Panel-Corrected Standard Errors ${ }^{a}$} \\
\hline & $\begin{array}{c}\text { Full Sample } \\
\text { (1) }\end{array}$ & $\begin{array}{c}\text { Full Sample } \\
\text { (2) }\end{array}$ & $\begin{array}{c}\text { Cities \& Okrugs } \\
\text { Excluded } \\
\text { (3) }\end{array}$ & $\begin{array}{c}\text { Industrial Core } \\
\text { (4) }\end{array}$ \\
\hline University & $\begin{array}{l}0.0000 \\
(0.0001)\end{array}$ & $\begin{array}{l}0.0000 \\
(0.0001)\end{array}$ & $\begin{array}{l}-0.0001 \\
(0.0001)\end{array}$ & $\begin{array}{l}0.0000 \\
(0.0001)\end{array}$ \\
\hline Household & $0.0290 * * *$ & $0.0326 * * *$ & $0.0636 * *$ & $0.0616 * *$ \\
\hline Expenditures & $(0.0077)$ & $(0.0093)$ & $(0.0250)$ & $(0.0251)$ \\
\hline Subsidies & $\begin{array}{l}0.0290 * \\
(0.0172)\end{array}$ & $\begin{array}{l}0.0117 \\
(0.0124)\end{array}$ & $\begin{array}{l}0.0439 \\
(0.0317)\end{array}$ & $\begin{array}{l}0.0318 \\
(0.0410)\end{array}$ \\
\hline Retention & $\begin{array}{l}0.1965 * * * \\
(0.0622)\end{array}$ & $\begin{array}{l}0.4140 * * * \\
(0.1414)\end{array}$ & $\begin{array}{l}0.5050 * * * \\
(0.1654)\end{array}$ & $\begin{array}{l}0.5364 * * * \\
(0.1824)\end{array}$ \\
\hline Transfers & $\begin{array}{l}-0.7003 * * * \\
(\mathbf{0 . 0 6 5 3})\end{array}$ & $\begin{array}{l}-0.2586 * \\
(0.1487)\end{array}$ & $\begin{array}{l}\mathbf{0 . 0 8 0 5} \\
(\mathbf{0 . 2 7 5 3 )}\end{array}$ & $\begin{array}{l}\mathbf{0 . 8 0 0 6} \\
(0.6049)\end{array}$ \\
\hline Retention * Transfers & & $\begin{array}{l}-0.6776 * * * \\
(0.2424)\end{array}$ & $\begin{array}{l}-1.1020 * * * \\
(0.3760)\end{array}$ & $\begin{array}{l}-2.3342 * * * \\
(0.8826)\end{array}$ \\
\hline Population & $\begin{array}{l}-0.0458 * * * \\
(0.0073)\end{array}$ & $\begin{array}{l}-0.0453 * * * \\
(0.0072)\end{array}$ & $\begin{array}{l}-0.0436 * * * \\
(0.0075)\end{array}$ & $\begin{array}{l}-0.0644 * * * \\
(0.0107)\end{array}$ \\
\hline Republic & $\begin{array}{l}0.0146^{* * *} \\
(0.0046)\end{array}$ & $\begin{array}{l}0.0100 * * * \\
(0.0035)\end{array}$ & $\begin{array}{l}0.0132 * * \\
(0.0051)\end{array}$ & \\
\hline Okrug & $\begin{array}{l}-0.1949 * * * \\
(0.0267)\end{array}$ & $\begin{array}{l}-0.1883 * * * \\
(0.0319)\end{array}$ & & \\
\hline City & $\begin{array}{l}0.0501 * * * \\
(0.0171)\end{array}$ & $\begin{array}{l}0.0289^{*} \\
(0.0170)\end{array}$ & & \\
\hline Obs & 315 & 315 & 297 & 201 \\
\hline$N$ & 80 & 80 & 75 & 51 \\
\hline$R^{2}$ & 0.4184 & 0.4299 & 0.4108 & 0.3284 \\
\hline Wald $\chi^{2}$ & 21458.71 & 3479.71 & 975.95 & 85.00 \\
\hline (prob.) & 0.0000 & 0.0000 & 0.0000 & 0.0000 \\
\hline $\begin{array}{l}\text { F-Test } \\
\text { (prob.) }\end{array}$ & & & & $\begin{array}{l}1.95 \\
0.0468\end{array}$ \\
\hline$\rho$ & 0.0324 & 0.0337 & -0.0236 & \\
\hline
\end{tabular}

Notes: Dependent variable is annual growth in gross regional product. Estimation is performed using OLS with errors corrected for contemporaneous correlation across panels. Panel-corrected standard errors are in parentheses. Time dummies are included in all regressions. Coefficients on time dummies and intercepts are not reported.

\subsection{Simultaneous Equation Models}

As is well known, situations in which the dependent variable and an explanatory variable are jointly determined by the simultaneous interaction of several relationships violate linear regression-model assumptions of strict exogeneity of the regressors. We have alluded to this potential problem in the use of transfers as a regressor. In the Russian system of revenue 
sharing, transfers were designed to alleviate longer-term income differences. Additionally, the reforms in the system of inter-governmental finance failed to eliminate completely centralregional bargaining for transfers. There is substantial evidence, for example, that autonomous republics with ethnic minorities exacted greater transfers than oblasts, or that the central government often used transfer funds as a method of co-opting wayward regional governors (Treisman 1996). A recent study shows that the transfer allocation in Russia contains a statistically significant bias that benefits regions located in the far northern parts of the country (Sinelnikov et al. 2001).

As such, it is likely that the ratio of total transfers received to the overall current revenue is not a strictly exogenous variable. To correct for this potential source of bias, then, we estimated the following system of simultaneous equations:

$$
\begin{aligned}
& T_{i t}=\beta_{0}+\beta_{1} y_{i t-1}+\beta_{2} \text { Expenditure }_{i t}+\beta_{3} \text { Resources }_{i t}+\beta_{4} \text { Subsidies }_{i t}+\beta_{5} \text { Population }_{i t}+\beta_{6} \mathbf{A}_{i t}+\mu_{i t} \\
& y_{i t}=\alpha_{0}+\alpha_{1} \text { Expenditure }_{i t}+\alpha_{2} \text { Resources }_{i t}+\alpha_{3} R_{i t}+\alpha_{4} T_{i t}+\alpha_{5}(R \times T)_{i t}+\alpha_{6} \mathbf{A}_{i t}+\varepsilon_{i t}
\end{aligned}
$$

where $\mathrm{y}$ is the familiar economic recovery index, expenditure, resources, and subsidies are variables defined in the previous section, $\mathrm{R}$ is the regional tax retention rate, $\mathrm{T}$ the transfers ratio, and $\mathbf{A}$ a vector of administrative dummies. We include the lagged recovery index, expenditures, resources, population, and subsidies in the first equation on the assumption that output decline, household income, natural-resource wealth, regional population, and level of subsidies can influence budgetary transfers, either through a formula-driven revenue-sharing scheme, or more likely, through the leverage of economically depressed, poorer, resource-poor, populous, highsubsidy regions in bargaining with federal authorities over the size of annual transfers.

Following previous work on the institutional determinants of growth, we employ threestage least squares (3SLS) to correct for simultaneity and the potential exogeneity of transfers in this system of equations. 3SLS - a systems counterpart to two-stage least squares (2SLS) - is generally recommended over 2SLS where the disturbances of the separate equations are correlated, and is thought to be consistent and asymptotically more efficient (Kennedy 1998, pp. 166-167). Our 3SLS-based estimates of the system of equations in (2) are reported in Table 5.

The panels in Table 5 correspond to the separate equations. When we allow for the possibility of simultaneous determination of transfers, our basic results hold. In the first panel, retention retains its positive, significant effect, and the interactive term retains its negative, significant sign. In the second panel, the results suggest, as expected, that transfers to regional budgets are indeed boosted by the depth of the regional economic depression, the demand for subsidies, and household poverty. Moreover, our results confirm other research on sub-national finance in the Russian Federation finding that autonomous republics and okrugs are more likely to demand (and receive) budgetary transfers. In the second column, we improve the overall specification by removing insignificant variables. Removing the resource indicator increases the number of observations to 261. In the larger sample, our previous results hold without exception. 
Table 5. Budgetary Transfers and Regional Output Recovery: Simultaneous Equation Results

\begin{tabular}{|c|c|c|c|}
\hline $\begin{array}{l}\text { Dependent } \\
\text { Variable } \\
\end{array}$ & Independent Variables & (1) & (2) \\
\hline \multirow{8}{*}{$\begin{array}{l}\text { Eqn. 2: } \\
\text { Recovery Index }\end{array}$} & Household Expenditures & $\begin{array}{l}0.0335 * * \\
(0.0151)\end{array}$ & \\
\hline & Resources & $\begin{array}{l}0.0008 \\
(0.0005)\end{array}$ & \\
\hline & Retention & $\begin{array}{l}0.9751 * * * \\
(0.2198)\end{array}$ & $\begin{array}{l}0.6092 * * * \\
(0.2090)\end{array}$ \\
\hline & Transfers & $\begin{array}{l}0.7361^{*} \\
(0.4114)\end{array}$ & $\begin{array}{l}-0.0080 \\
(0.3612)\end{array}$ \\
\hline & Transfers $\times$ Retention & $\begin{array}{l}-2.1260 * * * \\
(0.5772)\end{array}$ & $\begin{array}{l}-1.3285^{* *} \\
(0.5273)\end{array}$ \\
\hline & Republic & $\begin{array}{l}0.0189 \\
(0.0200)\end{array}$ & $\begin{array}{l}0.0456^{* *} \\
(0.0218)\end{array}$ \\
\hline & Okrug & $\begin{array}{l}0.0363 \\
(0.0567)\end{array}$ & $\begin{array}{l}0.1784 * * * \\
(0.0302)\end{array}$ \\
\hline & City & $\begin{array}{l}-0.1564^{* *} \\
(0.0652)\end{array}$ & $\begin{array}{l}-0.1253^{* *} \\
(0.0622)\end{array}$ \\
\hline \multirow{14}{*}{$\begin{array}{l}\text { Eqn. 1: } \\
\text { Transfers }\end{array}$} & Recovery Index $t_{t-1}$ & $\begin{array}{l}-0.5593 * * * \\
(0.0386)\end{array}$ & $\begin{array}{l}-0.6112 * * * \\
(0.0355)\end{array}$ \\
\hline & University & $\begin{array}{l}0.0001 \\
(0.0001)\end{array}$ & \\
\hline & Subsidies & $\begin{array}{l}0.0659 * * * \\
(0.0155)\end{array}$ & $\begin{array}{l}0.0716^{* * *} \\
(0.0159)\end{array}$ \\
\hline & Household Expenditures & $\begin{array}{l}-0.0124 \\
(0.0097)\end{array}$ & $\begin{array}{l}-0.0254^{* * *} \\
(0.0092)\end{array}$ \\
\hline & Resources & $\begin{array}{l}-0.0000 \\
(0.0003)\end{array}$ & \\
\hline & Population & $\begin{array}{l}-0.0760 * * * \\
(0.0077)\end{array}$ & $\begin{array}{l}-0.0507 * * * \\
(0.0070)\end{array}$ \\
\hline & Republic & $\begin{array}{l}0.0400^{* * * *} \\
(0.0133)\end{array}$ & $\begin{array}{l}0.0512 * * * \\
(0.0141)\end{array}$ \\
\hline & Okrug & $\begin{array}{l}0.0602 * \\
(0.0324)\end{array}$ & $\begin{array}{l}0.0603 * * \\
(0.0257)\end{array}$ \\
\hline & City & $\begin{array}{l}-0.0751 \\
(0.0517)\end{array}$ & $\begin{array}{l}-0.0304 \\
(0.0482)\end{array}$ \\
\hline & Obs & 236 & 261 \\
\hline & $R^{2} E q n .2$ & 0.7105 & 0.6553 \\
\hline & $\begin{array}{l}\chi^{2} \text { Eqn. } 2 \\
\text { (prob.) }\end{array}$ & $\begin{array}{l}717.50 \\
(0.0000)\end{array}$ & $\begin{array}{l}2152.16 \\
(0.0000)\end{array}$ \\
\hline & $R^{2}$ Eqn. 1 & 0.3727 & 0.3234 \\
\hline & $\begin{array}{l}\chi^{2} \text { Eqn. } 1 \\
\text { (prob.) }\end{array}$ & $\begin{array}{l}257.51 \\
(0.0000)\end{array}$ & $\begin{array}{l}293.71 \\
(0.0000)\end{array}$ \\
\hline
\end{tabular}

${ }^{*} \mathrm{p}<0.10,{ }^{* *} \mathrm{p}<0.05, * * * \mathrm{p}<0.01$

Notes: Dependent variable is cumulative regional output decline since 1990 in equation 1, transfers from the federal government as a percentage of regional revenue for equation 2. Coefficients are obtained using threestage least squares estimation, using a covariance matrix of the equation errors adjusted for small samples. Intercepts and time dummies are included in both equations and both regressions, but are not reported. 
Results of the interactive hypotheses tested here may be seen graphically in Figure 3, which plots the expected conditional effect of natural resource abundance and budgetary transfers on the relationship between retention rates and cumulative output growth, using regressions (2) and (1) from Tables 3 and 5, respectively. The vertical axis presents the conditional effect of retention rate on recovery, and the two lines are plotted over the maximum range of fractions of output derived from natural resources, and transfers in total revenues (i.e, zero to 1). The figure suggests that the effect of retention on growth "switches" from positive to negative when transfers constitute more than $45 \%$ of total revenues. No such switching occurs for resource wealth, and the effect of retention rates on growth is positive but declining in magnitude as regions become more resource abundant.

Figure 3. Conditional Effects of Tax Retention on Regional Economic Recovery

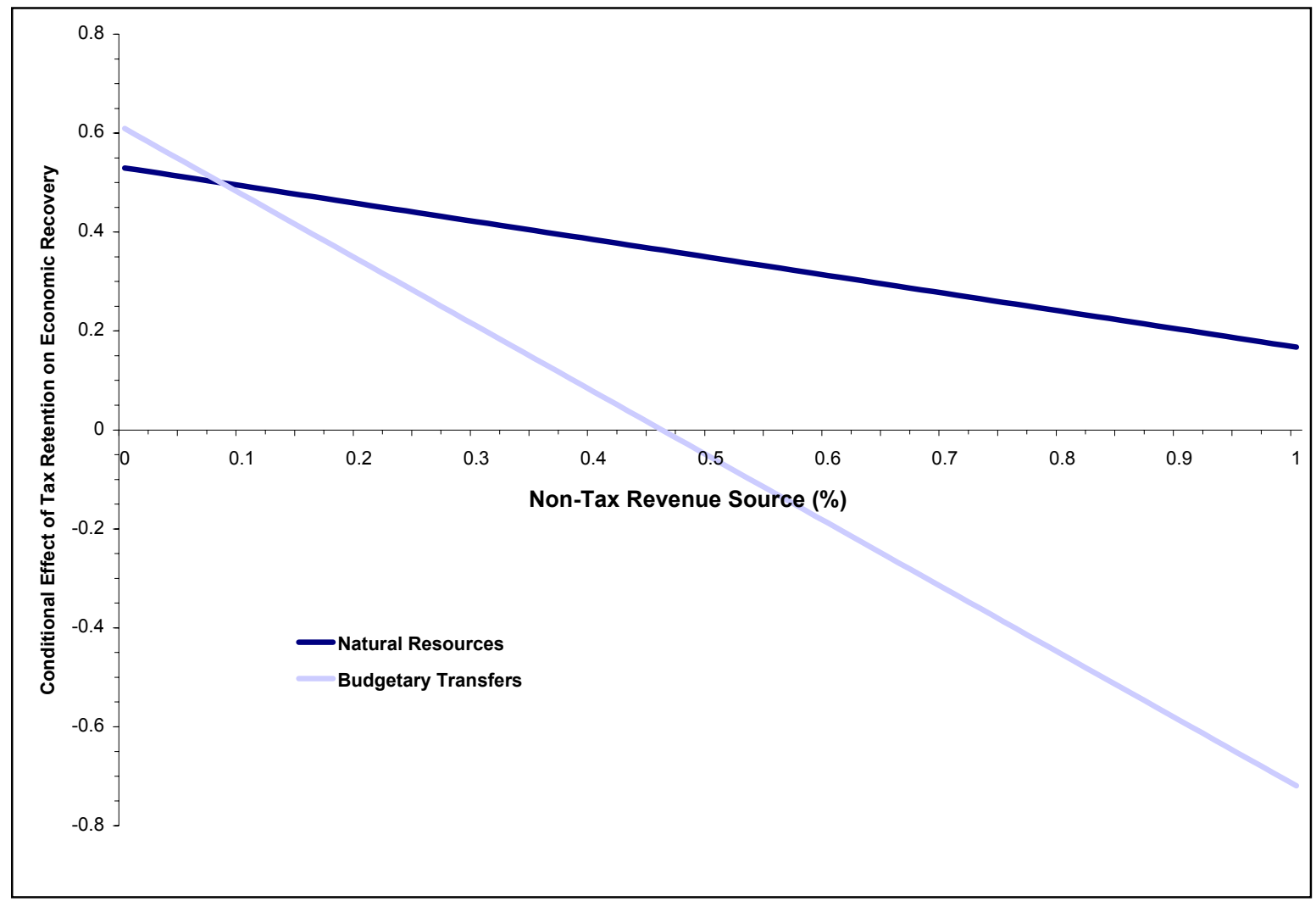




\section{Conclusion}

This paper finds statistical evidence in support of the hypothesis that fiscal incentives of the Russian regions represent an important determinant of regional economic performance. Since the mid-1990s, some degree of centralized control has been reasserted in the Russian Federation, along with more uniform rules for revenue sharing and expenditure assignment. These reforms have achieved mixed results. In general, re-centralization has improved the transparency of inter-governmental fiscal relations, but has naturally increased federal control over regionally generated tax revenues.

Our results suggest that an increase in the retention rate (a share of locally generated taxes that are left with the regional budgets) for most regions is generally accompanied by stronger economic growth. This confirms the view that tax sharing arrangements could play a critical role in establishing incentives supportive of local development: regions that face a higher retention rate tend to be more interested in developing the local tax base, and thus are more interested in investing in the improvement of the business environment and providing support for new business entry and genuine enterprise restructuring. This finding emphasizes once again a need for advancing reforms in fiscal federalism in Russia. Excessive fiscal centralization as well as frequent changes in the fiscal arrangements indeed is and has been detrimental to sustainable economic growth.

In addition to decentralization of resources through greater retention, decentralization of decisions on taxation, i.e. genuine tax autonomy, is needed to ensure robust local incentives to broaden the tax base. Otherwise, if most decisions on tax sharing are centralized, the high retention may fail to create longer-term growth incentives: regions would still face a risk of sudden drastic change in the rules of tax sharing by a decision of the central government. The effect of high retention rate would be the most significant, if it is realized not though a tax sharing of central government's taxes, but instead through a developed system of local taxes. Real tax autonomy represents a critical institutional mechanism of sharing gains from economic growth within the location, and thus providing for pro-growth incentives for local governments. Intergovernmental tax sharing has been reduced since 2000, and this separation should be further advanced to fully distringuish the tax bases of the various levels of government.

At the same time, our results suggest that the impact of expanding regional fiscal autonomy is not uniformly beneficial for the local economy. Where a large portion of regional revenues derives from "unearned" income streams rather than local taxation, the effect of fiscal autonomy weakens. We have identified two types of regions that face such a risk of excessive competition for rents: regions with high shares of revenues deriving from the energy sector (including oil and gas) and regions that are highly dependent on federal transfers. In both cases the effect of fiscal autonomy on regional growth eroded as the share of non-tax revenues in the form of resource production or budgetary transfers rose. Our results suggest that increasing tax retention rates has the strongest effect on regional economic performance in relatively rent-free regions. These findings support, moreover, the explanations - outlined in the introduction - of the sources of success in Chinese-style fiscal federalism: local autonomy combined with political centralization. As Chinese provinces have benefited from higher and more stable tax retention, the central government had preserved administrative control over these provinces, strictly limiting opportunities for rent-seeking. 
This paper has identified certain limits of fiscal autonomy in resource-rich or transferdependent regions. The central policy implication of these results is that fiscal autonomy may be insufficient to transform regions in federal Russia into truly "market-preserving" entities without improvements in revenue-side management in the regions. Our results could be interpreted as an argument in favor of an "asymmetrical" federalism across different regions based on their economic conditions. ${ }^{9}$ While additional fiscal autonomy for most Russian regions is justifiable, regions that are prone to rent seeking may require special fiscal regimes. For transfer-dependent economically depressed regions, this argument would suggest some restrictions in their fiscal autonomy to create an opportunity for broader central government's control over their expenditure policy - a proposal in line with ideas recently proposed for external fiscal management of fiscally-depressed and bankrupt regions. ${ }^{10}$ In the case of resource-wealthy regions, it may require a much higher degree of centralization of natural resource revenues at the federal level to reduce risks of respective regional governments to become a victim of natural resource curse. To avoid accumulation of problems with the transfer dependence, additional federal revenues from the natural resource rent should not necessarily be distributed back to poorer regions as federal transfers. Instead, such incremental revenues could be used to finance public infrastructure projects in low-income regions through federal investment programs.

\footnotetext{
${ }^{9}$ On the concept of "asymmetry" in Russian fiscal federal relations, see Lapidus (1999) and Bahry (2001).

${ }^{10}$ For recent proposals to this effect, see e.g., Yasin (2002).
} 


\section{REFERENCES}

Arhend, R. 2000. "Speed of Reforms, Initial Conditions, Political Orientation, or What? Explaining Russian Regions' Economic Performance." Presented at the CERP/WDI Annual International Conference, Moscow.

Bahry, Donna. 2001. "Rethinking Asymmetrical Federalism," in Rafael Khakimov ed. Federalism in Russia. Kazan: Tatarstan Academy of Sciences/Kazan Institute of Federalism.

Beck, Nathaniel, and Jonathan N. Katz. 1995. "What to Do (and Not to Do) with Time-Series Cross-Section Data." American Political Science Review 89 (3): 634-47.

Beck, Nathaniel, and Jonathan N. Katz. 1996. "Nuisance Vs. Substance: Specifying and Estimating Time-Series-Cross-Section Models." Political Analysis 6 (1): 1-36.

Blanchard, Olivier, and Andrei Shleifer. 2001. "Federalism with and without Political Centralization: China Versus Russia." IMF Staff Papers 48: 171-208.

Center for Economic and Financial Research. 2003. Montoring the Administrative Barriers to Small Business Development in Russia. Moscow: CEFIR.

Chaudhry, Kiren Aziz. 1997. The Price of Wealth: Economies and Institutions in the Middle East. Ithaca: Cornell University Press.

Desai, Raj M., and Itzhak Goldberg. 2001. "The Politics of Russian Enterprise Reform: Insiders, Local Governments, and the Obstacles to Restructuring." World Bank Research Observer 16 (2): 219-40.

Dolinskaya, Irina. 2001. "Transition and Regional Inequality in Russia: Reorganization or Procrastination?" Typescript. IMF Institute, Washington, D.C.

Esanov, Akram, Martin Raiser, and William Buiter. 2001. "Nature'S Blessing or Nature'S Curse: The Political Economy of Transition in Resource-Based Economies." Working Paper 65. EBRD, London.

Freinkman, Lev M., and Michael Haney. 1997. "What Affects the Propensity to Subsidize: Determinants of Budget Subsidies and Transfers Financed by the Russian Regional Governments in 1992-1995." Policy Research Working Paper 1818. World Bank, Washington, DC.

Freinkman, Lev M., Daniel Treisman, and Stepan Titov. 1999. "Subnational Budgeting in Russia: Preempting a Potential Crisis." Technical Paper 452. World Bank, Washington, DC. 
Freinkman, Lev M., and Plamen Yossifov. 1999. "Decentralization in Regional Fiscal Systems in Russia: Trends and Links to Economic Performance." Policy Research Working Paper 2100. World Bank, Washington, DC.

Huang, Yasheng. 1994. "Information, Bureaucracy, and Economic Reforms in China and the Soviet Union." World Politics 47: 102-34.

Jin, Hehui, Yingyi Qian, and Barry Weingast. 2000. "Regional Decentralization and Fiscal Incentives: Federalism, Chinese Style." Working Paper. Hoover Institution, Stanford, Calif.

Kennedy, Peter. 1998. A Guide to Econometrics. 4th ed. Cambridge, Mass.: MIT Press.

Knack, Stephen F. 2000. "Aid Dependence and the Quality of Governance: A Cross-Country Empirical Analysis." Policy Research Working Paper 2396. World Bank, Washington, D.C.

Kuznetsova, Olga. 2001. "Economicheskaya Politika Regional'nykh Organov Vlasti." Presented at the 3rd International Conference on Public Sector Reforms, St. Petersburg.

Lapidus, Gail W. 1999. "Asymmetrical Federalism and State Breakdown in Russia." Post-Soviet Affairs 15 (1): 74-82.

Lavrov, A. 1996. "Fiscal Federalism and Financial Stabilization." Problems of Economic Transition 39 (1): 83-94.

Lavrov, Alexei, John M. Litwack, and Douglas Sutherland. 2001. Fiscal Federalist Relations in Russia. Paris: OECD.

Leite, Carlos, and Jens Weidmann. 1999. "Does Mother Nature Corrupt? Natural Resources, Corruption, and Economic Growth." Working Paper WP/99/85. International Monetary Fund, Washington, D.C.

Levi, Margaret. 1988. Of Rule and Revenue. Berkeley: University of California Press.

McKinsey \& Co. 1999. Unlocking Economic Growth in Russia. Washington, DC: McKinsey Global Institute.

Montinola, Gabriella, Yingyi Qian, and Barry Weingast. 1994. "Federalism, Chinese Style: The Political Basis for Economic Success in China." World Politics 48 (1): 50-81.

Moore, Mick. 1998. "Death without Taxes: Democracy, State Capacity, and Aid Dependence in the Fourth World," in M. Robinson and G. White eds. The Democratic Developmental State: Political and Institutional Design. Oxford: Oxford University Press.

Popov, Vladimir. 2001. "Reform Strategies and Economic Performance of Russia's Regions." World Development 29 (5): 865-86. 
Radayev, Vadim. 1996. "Malyi Bisnes I Problemy Delovoi Etiki." Nadezhdy i Real'nost Voprosy Ekonomiki 7: 72-82.

Ross, Michael L. 2001. "Does Oil Hinder Democracy?" World Politics 53 (3): 325-61.

Sachs, Jeffrey, and Andrew M. Warner. 2001. "The Curse of Natural Resources." European Economic Review 45 (4-5): 827-38.

Shleifer, Andrei, and Daniel Treisman. 2000. Without a Map: Political Tactics and Economic Reform in Russia. Cambridge, Mass.: MIT Press.

Sinelnikov, Sergei, Pavel Kadochnikov, Ilya Trunin, and Yekaterina Shrebela. 2001. Vliyaniye Mezibyudzetnykh Transfertov Na Fiscal'noye Povedeniye Regional'nykh Vlastei V Rossiiskoi Federatsii. Moscow: Institute of Economic Transition.

Speck, Stefan, and Alexander P. Matusevich. 2002. "Taxation Policy Reform in the Russian Federation: Challenges and Obstacles for Implementation of Environmentally Related Taxes." Typescript. OECD, Paris.

Stoner-Weiss, Kathryn. 2001. "Whither the Central State? The Regional Sources of Russia's Stalled Reforms." Typescript. Princeton University, Center of International Studies, Princeton, N.J.

Tilly, Charles, and Gabriel Ardant. 1975. The Formation of National States in Western Europe. Princeton, N.J.: Princeton University Press.

Tornell, Aaron, and Philip R. Lane. 1999. "The Voracity Effect." American Economic Review 89: $22-46$.

Treisman, Daniel. 1996. "The Politics of Intergovernmental Transfers in Post-Soviet Russia." British Journal of Political Science: 299-335.

Treisman, Daniel. 1999. After the Deluge: Regional Crises and Political Consolidation in Russia. Ann Arbor, Mich.: University of Michigan Press.

Yasin, Yevgeny, ed. 2002. Bremya Gosudarstva I Ekonomicheskaya Politika: Liberal'naya Alternativa. Moscow: The Expert Institute.

Zhuravskaya, Ekaterina V. 1999. "Incentives to Provide Local Public Goods: Fiscal Federalism, Russian Style." Working Paper 153. Stockholm, SITE. 